\title{
Integrating social responsibility considerations into PCR model: an application of China's electricity price regulation
}

\author{
Qing Huang ${ }^{1, *}$ \\ 1 State Grid Energy Research Institute \\ Beijing, China \\ *huangqing@sgeri.sgcc.com.cn
}

\begin{abstract}
Price cap regulation (PCR) has experienced widespread adoption in some countries' electricity sector. In current China's electric power transmission-distribution price reform, the cost plus revenue regulation model has been adopted for the supervision over electric power transmission-distribution price, and such model has certain incentive function, so China is at a transition period from traditional regulation to incentive regulation. Price cap regulation is a widely used incentive regulation model. Considering that China's electric power grid enterprises undertake huge social responsibility, it is necessary to reform the traditional price cap model in order to compensate the large amount of cost contributed by enterprises for performing their social responsibility, which has great significance to the sustainable development of the society and electric power enterprises. This paper studies the price cap regulation features and its application, discusses China's electric power transmission-distribution regulation models, and finally proposes suggestions on the reform to traditional price cap regulation model based on the consideration on the social responsibility factor.
\end{abstract}

Keywords: Social Responsibility, Price Cap, Regulation, Transmission-distribution Price, Incentive Regulation.

\section{Introduction}

Incentive regulation includes price cap, revenue cap, yardstick competition and other regulation and pricing models. It requires the regulation authority to apply less interference and spend less regulation expense. In order to bypass the inadequate efficiency of traditional regulation, more and more countries are switching to adopt incentive regulation model.

Price cap is in essence an agreement between the government or the regulation authority and those enterprises subject to regulation, and a kind of effective regulation solution to be applied in circumstances where enterprises have better understanding and knowledge to their own advantages in technology and cost than the regulation authority - the regulation authority sets up a price cap (average price or weighted price) for all products or for a blanket of products, under which enterprises have discretionary power to finalize their own price. The maximum price finalized in the first year will be subject to adjustment in coming years based on predefined economic index and factor collection. The general form of price cap is:

$$
\mathrm{P}_{\mathrm{j}, \mathrm{t}}=\left[\mathrm{P}_{\mathrm{j}, \mathrm{t}-1} \cdot(1+\mathrm{RPI}-\mathrm{X})\right] \pm \mathrm{Z}
$$

$\mathrm{P}_{\mathrm{j}, \mathrm{t}}=$ the maximum price charged to Class $\mathrm{j}$ consumers in Year $\mathrm{t}$; RPI = retail price index, i.e., rate of inflation; $\mathrm{X}=$ production efficiency compensation factor, i.e., the percentage of enterprise production efficiency increase during a certain period of time defined by the regulation authority; $Z=$ adjustment to incidentals. Price cap regulation is a "blanket price" regulation, where the difficulty is the determination of the efficiency coefficient value X. Looking at the practice of UK in regulation, Value $\mathrm{X}$ depends on the technical and economic nature of the industry and the cost variation arising from progress of technology, and has significant difference among different industries even among different regions of a same industry. Value $\mathrm{X}$ of power grid operating enterprise ranges 0-3\%. Price cap regulation now has been widely applied to US telecommunication PBR regulation and UK power distribution regulation. 


\section{China's Practice in electricity price regulation}

Specific to the actual conditions in China, in setting up the objectives of the power transmission-distribution price regulation, the first thing is to make adequate consideration on the current status of power transmission-distribution price, as well as the demands of the regulation authority and those subject to such regulation; secondly, effective incentive initiatives shall be made to those enterprises subject to regulation for improving their efficiency, so that the benefits of electric power consumers are protected while the survival and development of enterprises are preserved; this effort is to stimulate enterprise to make active investment to power grid construction, and, to ensure electric power quality requirement.

Along with the deepening of electric power market-oriented reform and taking-apart of each phase, different regulation methods and measures shall be applied to each phase according to its different features. In electric power generation and electricity selling phases, loose the regulation and encourage competition; in electric power transmission and distribution phase, strict regulation still shall be applied for the current period, but the regulation method and means shall be innovated, as such, PBR model now has been widely used in the electric power industries in many countries, due to, as the main characteristics of it, the weakening of the interrelationship between enterprise cost and its price, and the strong compatibility to introduced competition.

Currently and in the process of this round of power transmission-distribution price reform, China has established a cost plus revenue regulation model to power transmission-distribution price, which is featured of incentive function, to some extent. As specific to China's electric power transmission and distribution regulation, PBR model may realize the maximized utilization of existing assets and produce incentive initiatives for improving operation efficiency and other functions. Among these functions, price cap regulation, revenue cap regulation and other models may enable those enterprises subject to regulation to be benefited from reasonable cost compensation and gaining normal profit, while improving user's satisfaction; and it is a truly win-win model.

In order to achieve a sound incentive effect and avoid the impact of information asymmetry on regulation, price cap regulation or traditional regulation and yardstick competition regulation model is general used, based on which, by introducing performance benchmarking to give incentive initiatives for encouraging efficiency varied enterprise to improve their efficiency, the overall electric power grid efficiency can be improved; also, the practice of the regulation models combined with several regulation modes by the electric power companies of US different states can be referenced in our practice. Of course, price cap model still has disadvantages, such as, inability to reflect demand for electric power and insignificant stimulation to investment, etc., and all of these limits shall be fully considered and optimized in China's practice of power transmission-distribution price regulation models.

\section{Price cap regulation model with Social responsibility factors}

Since the application of price cap regulation to the price regulation of natural monopoly industries by UK government, the purpose is to maintain the price and the enterprise profit at a level where there is no unfairness but a space to stimulate enterprises to improve their efficiency, and the application of price regulation requires to distinguish the source varied profits by linking the regulation price and retail price index with production efficiency. Currently, price cap regulation has been widely and globally used in energy, telecommunication, transportation and tap water and other utility sectors. However, price cap regulation contains a number or defects restricting incentive effectiveness such as regulation capture, missing of regulation commitment and decreased product or service quality.

Differing from foreign electric power enterprises, China electric power grid enterprises assume social responsibility in addition to the responsibility for supplying electric power in a safe and high-efficient way. Enterprises are required to achieve not only the economic benefit for own survival and development but also the social benefit, in which process, they were chasing maximized economic, social and environmental benefits, and contributing huge human and financial resources in performing their social responsibility. No consideration has been made to the factor of social 
responsibility in the framework of traditional price cap model; therefore, it is necessary to reform such traditional model in the supervision on current electric power transmission and distribution price of power grid enterprises, so as to give better systematic description of the price regulation model applied to those enterprises performing social responsibility.

$$
\mathrm{P}_{\mathrm{j}, \mathrm{t}}=\left[\mathrm{P}_{\mathrm{j}, \mathrm{t}-1} \cdot(1+\mathrm{RPI}-\mathrm{X}+\mathrm{SR})\right] \pm \mathrm{Z}
$$

$\mathrm{P}_{\mathrm{j}, \mathrm{t}}=$ maximum price being charged to Class $\mathrm{j}$ users in Year $\mathrm{t}$; RPI $=$ retail price index, i.e., rate of inflation; $X=$ production efficiency compensation factor, i.e., the percentage growth of enterprise production efficiency during a certain period of time stipulated by the regulation authority; SR = social responsibility adjustment factor, i.e., the adjustment to enterprise social responsibility assuming index during a period of time stipulated by the regulation authority; $Z=$ the adjustment to incidentals.

The construction of SR index can be made from four Grade I dimensions namely of universal service, public welfare donation, serving to the development of clean energy and energy-saving/emission reduction, and then, representative index is selected in each dimension by using analytic hierarchy process. In terms of universal service, consideration shall be made to the following indices: investment to rural power grid, accumulative new power-accessed households, and the difference of outage time between new power-accessed households and urban power-accessed households; in terms of public welfare donation, consideration shall be made to the following indices: total amount of donation and voluntary service contributed by employees; in terms of serving to clean energy, consideration shall be made to the following indices: the grid-connected capacity of clean energy source generation set and the on-grid electric power quantity of clean energy source generation set; in terms of energy saving and emission reduction, consideration shall be made to the following indices: the reduced emission of $\mathrm{CO}_{2}$ by assuming clean energy, the reduced line loss emission reduction and saved electricity, etc. Based on the index system constructed as described in the above, comprehensive evaluation method is then adopted to estimate the social responsibility index of electric power grid companies.

\section{Conclusions}

In current China's reform in electric power transmission and distribution price, cost plus revenue regulation model has been initially defined for electric power transmission and distribution price regulation, where certain incentive role exits, and which represents a transition period from traditional regulation to incentive regulation. In the future, China will certainly be moved to incentive regulation pattern. Price cap regulation is a widely used incentive regulation model. When applying price cap regulation model in some developed countries, instead of simply setting up the upper limit of price, they established a series of supporting measures specific to restricting the defects existed in price cap regulation model; all these measures are essential to the effectiveness of price cap regulation model, also the difference depending on the national conditions of different countries.

Considering that China's electric power grid enterprises undertake huge social responsibility, it is necessary to reform the traditional price cap model in order to compensate the large amount of cost contributed by enterprises for performing their social responsibility, which has great significance to the sustainable development of the society and electric power enterprises. Based on this consideration, it is necessary for us to construct a well-defined regulation system and strengthen quality control for achieving the win-win outcome of enterprise and social development.

\section{References}

[1] Tsai, C., 2011. The reform paradox and regulatory dilemma in China's electricity industry. Asian Surv. $51(3), 520 \mathrm{e} 539$.

[2] Wang, Q., Chen, X., 2011. China's electricity market-oriented reform: from an absolute to a relative monopoly. Energy Policy 51, 143e148. 
[3] Sappington, D. Regulating service quality: A survey. Journal of Regulatory Economics, 2005, 27(2), 123-154.

[4] Sappington, D., Pfeifenberger, J., Hanser, P. \& Basheda, G. Status and trends of performance-based regulation in the U.S. electric utility industry. The Electricity Journal, 2001, 14(8), 71-79.

[5] Vogelsang, I. Incentive regulation and competition in public utility markets: A 20-year perspective. Journal of Regulatory Economics,2002, 22(1), 5-27.

[6] Vogelsang, I. (2010). Incentive regulation, investments and technological change. Boston University Working Paper.

[7] Weisman, D. Price regulation and quality. Information Economics and Policy, 2005, 17(2), $165-174$.

[8] David E. M. Sappingtona, Dennis L. Weismanb. The price cap regulation paradox in the electricity sector. The Electricity Journal, 2016, 29 1-5.

[9] Gurcan Gulen and Michael Soni. The Impacts of Raising the Energy Price Cap in ERCOT. The Electricity Journal, 2013, Vol. 26, Issue 7 43-54.

[10] Laura Abrardi, Carlo Cambini. Tariff regulation with energy efficiency goals. Energy Economics. 49 (2015) 122-131. 